\title{
Efficacy of immunization against hepatitis B virus infection in acute leukemia
}

\author{
Akut lösemide hepatit B virüsü enfeksiyonuna karşı aşılama etkililiği
}

\author{
Tuphan Kanti Dolai, Manoranjan Mahapatra, Hara Prasad Pati, Pravas Mishra, \\ Tulika Seth, Rahul Bhargava, Shyam Rathi, Niranjan Rathod, Renu Saxena \\ All India Institute of Medical Sciences (AIIMS), New Delhi, India
}

\begin{abstract}
Objective: The aim of this study was to assess the antibody response to combined passive-active immunization versus active immunization against hepatitis $B$ in 71 patients with acute leukemia with negative hepatitis B virus serology at presentation.

Materials and Methods: The first group $(n=28)$ received a double dose of hepatitis $B$ vaccine at 0,1 , 2 and 6 months and immunoglobin (HBIG) at 0 and 1 month concurrently with vaccine but at a different intramuscular site. The second group $(n=43)$ received double dose of hepatitis $B$ vaccine at 0 , 1,2 , and 6 months. HBsAg and anti-HBs titers were determined one month after the $1^{\text {st }}, 2^{\text {nd }}, 3^{\text {rd }}$ and $4^{\text {th }}$ doses of vaccine.

Results: In the vaccine-only group, $2.56 \%, 8.33 \%, 14.28 \%$ and $34.29 \%$ of patients developed anti-HBs titer $\geq 10 \mathrm{IU} / \mathrm{L}$ after the $1^{\text {st }}, 2^{\text {nd }}, 3^{\text {rd }}$ and $4^{\text {th }}$ doses of vaccine, respectively. In the HBIG group, $91.30 \%$, $91.30 \%, 69.56 \%$ and $73.91 \%$ of patients developed anti-HBs titer $\geq 10 \mathrm{IU} / \mathrm{L}$ after the $1^{\text {st }}, 2^{\text {nd }}, 3^{\text {rd }}$ and 4th doses of vaccine, respectively. Those in the vaccine-HBIG group maintained their anti-HBs titer $\geq 10 \mathrm{IU} / \mathrm{L}$ from the $1^{\text {st }}$ to the $4^{\text {th }}$ doses. In the vaccine-only group, $34.29 \%$ of patients gained protective antibody titer after receiving the $4^{\text {th }}$ dose of vaccine. Subgroup analysis of age (pediatric vs adult) and disease (acute lymphoblastic leukemia vs acute myeloid leukemia) groups showed no effect of either on the development of protective antibody titer. The incidence of $\mathrm{HBsAg}$ positivity one month after the $4^{\text {th }}$ dose of vaccine was $8.62 \%$. No patient became positive for anti-HCV or HIV antibody before or after chemo therapy.

Conclusion: Combined HBIG and vaccine may protect acute leukemia patients during the intensive chemotherapy period. (Turk J Hematol 2010; 27: 156-61)
\end{abstract}

Key words: Acute leukemia, hepatitis B vaccine, hepatitis B immunoglobin

Received: May 27, 2009

Accepted: April 30, 2010

Özet

Amaç: Bu çalışmada, prezantasyonda negatif Hepatit B virüsü serolojisine sahip akut lösemili 71 hastada Hepatit B virüsüne karşı aktif aşılama karşısında birleşik pasif aktif aşılamaya yönelik antikor yanıtının değerlendirilmesi amaçlanmıştır. 
Yöntem ve Gereçler: Birinci grup $(n=28), 0$. ay, 1. ay, 2. ay ve 6. ay zaman noktalarında ikili hepatit B aşısı dozu ve 0 . ay, 1. ay zaman noktalarında aşı ile eşzamanlı olarak (ancak kas içi olarak) immunoglobin (HBIG) almıştır. İkinci grup $(n=43), 0$. ay, 1. ay, 2. ay ve 6. ay zaman noktalarında ikili hepatit B aşısı dozu almıştır. HBsAg ve anti HBs titreleri, aşının 1. dozu, 2. dozu, 3. dozu ve 4. dozundan sonra yapılmıştır.

Bulgular: Yalnızca aşı yapılan grupta hastaların \%2.56, \%8.33, \%14.28 ve \%34.29'unda, sırasıyla 1., 2., 3. ve 4. aşı dozu verildikten sonra anti $\mathrm{HBs}$ titresi $\geq 10 \mathrm{IU} / \mathrm{l}$ oluşmuştur. HBIG grubunda, hastaların $\% 91.30, \% 91.30, \% 69.56$ ve $\% 73.91$ 'inde, sırasıyla $1 ., 2 ., 3$. ve 4. aşı dozu verildikten sonra anti $\mathrm{HBs}$ titresi $\geq 10 \mathrm{IU} / \mathrm{l}$ oluşmuştur. HBIG alan hastalar, 1. dozdan 4. doza kadar $\geq 10 \mathrm{IU} / \mathrm{l} \mathrm{HBs} \mathrm{titre} \mathrm{değerini}$ muhafaza etmiştir. Yalnızca aşı verilen grupta, hastaların \%34.29'u 4. aşı dozu verildikten sonra koruyucu antikor titresi edinmiştir. Yaş (yetişkin karşısında pediatrik) ve hastalık (akut myeloid lösemi karşısında akut lenfoblastik lösemi) gruplarında, koruyucu antikor titresi gelişimi bakımında herhangi bir etki gözlenmemiştir. Aşının 4. dozundan bir ay sonar HBsAg pozitivite insidansı \%8.62'dir. Kemoterapiden önce sonra, hiçbir hastada anti HCV ve HIV antikoru için pozitivite gelişmemiştir. Sonuç: Kombine HBIG ve aşı, yoğun kemoterapi periyodu sırasında akut lösemi hastalarını koruyabilir. (Turk J Hematol 2010; 27: 156-61)

Anahtar kelimeler: Akut lösemi, Hepatit B aşısı, Hepatit B immunoglobin

\section{Introduction}

Hepatitis B is one of the most important causes of acute and chronic hepatitis. Children with malignant disease are at an especially high risk for developing hepatitis B virus (HBV) infection from immunosuppression secondary to chemotherapy, radiotherapy and multiple blood transfusions. Most of the children infected with HBV develop chronic hepatitis. This plays an adverse prognostic role in terms of their disease-free survival because of delays in chemotherapy. The increasing potential for the cure of childhood malignant diseases emphasizes the need for a method of reducing hepatitis and its sequelae in these children.

Hepatitis B virus infection is prevalent in India. Among blood donors, pregnant women and the general population whose carrier frequency is $2 \%-4 \%$ and hepatitis B surfact antibody (anti-HBs) positivity is around 18\%-20\% [1]. A high proportions of children treated for malignant disorders demonstrate seroconversion for HBV infection markers [2].

The high prevalence of HBV infection and relative failure of active immunization in patients with leukemia on therapy have prompted a search for alternative forms of prophylaxis [3]. Various studies have observed a decreased rate of transmission of the infection with passive immunization [4]. Thus, for protection against HBV infection, both active and passive immunization have been tried $[5,6]$.

Since there are very few studies in this context, this study was undertaken to determine the efficacy of immunization (both active and passive) against HBV infection in acute leukemia patients.

\section{Materials and Methods}

The aims and objectives of this study were to determine the incidence of hepatitis B surface antigen (HBsAg) positivity before treatment, the efficacy of hepatitis B vaccine along with HBIG (hepatitis B immunoglobulin) in patients with acute leukemia, the anti-HBs titer level in the course of treatment and up to six months, and the HBsAg positivity rate in the course of treatment up to six months. A total of 114 patients with acute leukemia were tested for HBsAg and anti-HBs titer before starting treatment. Of the 114 patients, 3 were positive for HBsAg and 111 patients were negative for HBsAg. Out of 111 patients, 40 had anti-HBs titer $\geq 10 \mathrm{IU} / \mathrm{L}$ and 71 patients had anti-HBs titer $<10 \mathrm{IU} / \mathrm{L}$. Thus, 71 patients were included in this study. This project was approved by the All India Institute of Medical Sciences (AIIMS) Ethics Committee. It is a prospective comparative trial including patients with acute leukemia with HBsAg, anti-HBs negativity before treatment and with anti-HBs titer $<10 \mathrm{IU} / \mathrm{L}$. Those patients already immunized and with protective anti-HBs titer $\geq 10$ IU/L were excluded from the study. Those who already completed immunization against hepatitis $B$ and with anti-HBs titer $<10 \mathrm{IU} / \mathrm{L}$ were also included in this study. Immunization was started from induction. The first group $(n=28)$ received hepatitis $\mathrm{B}$ vaccine (Engerix $\mathrm{B}$ GlaxoSmithKline Biologicals, double dose, i.e. $\leq 11$ years $20 \mathrm{mcg}$ and $>11$ years $40 \mathrm{mcg}$ ) at $0,1,2$, and 6 months and HBIG (Hepabig- VHB Life Sciences Limited, Mumbai, India at a dose of $40 \mathrm{IU} / \mathrm{kg}$ maximum of $800 \mathrm{IU}$ ) at 0 and 1 month concurrently with 
Engerix B but at a different intramuscular site. The second group $(n=43)$ received only hepatitis $B$ vaccine (Engerix B - double dose, i.e. $\leq 11$ years $20 \mathrm{mcg}$ and $>11$ years $40 \mathrm{mcg}$ ) at $0,1,2$, and 6 months.

HBsAg and anti-HBs titer were determined one month after the 1st, 2nd, 3rd and 4th doses of vaccine. In those patients who were given Engerix B and HBIG and became HBsAg positive after starting treatment, subsequent doses of Engerix B and HBIG were not given. Anti-hepatitis $\mathrm{C}$ virus (HCV) total and human immunodeficiency virus (HIV) antibody were also tested before starting treatment and one month after the 4th dose of vaccine. HbsAg was tested using Hepanostika ${ }^{\circledR}$ HBsAg Ultra (bioMerieux bv Boseind 15, 5281RM Boxtel, The Netherlands). Anti-HBs was tested using $\operatorname{VIDAS}^{\circledR}{ }^{\circledR}$ (bioMérieux ${ }^{\circledR}$ sa, France).

Fisher's exact test and chi-square test were used to compare proportions between the groups. McNemar test was used to compare proportions within the group. Wilcoxon rank-sum (MannWhitney U) test was used to compare the medians. Two-sample $t$ test was used to compare the median between the groups in equal variances. The statistical tests were performed by using STATA 9.0 and SPSS software version 11.5 for Windows ${ }^{\circledR}$.

\section{Results}

Of these 114 patients, 3 (3\%) were positive for HBsAg and 111 patients (97\%) were negative for HBsAg. Out of 111 patients, 40 (36\%) had anti-HBs titer $\geq 10 \mathrm{IU} / \mathrm{L}$ and 71 (64\%) had anti-HBs titer $<10$ IU/L. Of those patients with anti-HBs titer $\geq 10 \mathrm{IU} / \mathrm{L}$, 7 (18\%) patients had past history of jaundice, 13 (33\%) had history of previous vaccination and 20 (49\%) had no history of jaundice or previous vaccination. A significant statistical difference $(p=0.04)$ was found between pediatric and adult patients in anti-HBs titer $\geq 10 \mathrm{IU} / \mathrm{L}$ and anti- HBs titer $<10 \mathrm{IU} / \mathrm{L}$ groups. The majority of pediatric patients had antiHBs titer $\geq 10$ IU/L compared to adults before starting chemotherapy.

The median age was 22 years (range, 1-52); 49 (69.01\%) were male and 22 (30.99\%) were female (Table 1). The total number of pediatric ( $\leq 18 \mathrm{yrs}$ ) patients was $31(43.66 \%)$ and of adult (>18 yrs) patients was 40 (56.34\%). The total number of acute lymphoblastic leukemia (ALL) patients was 38 (53.52\%) and of acute myeloid leukemia (AML)

\begin{tabular}{lccc} 
Table 1. Baseline patient characteristics according to vaccine group \\
\hline Parameters & $\begin{array}{c}\text { HBIG-Vaccine } \\
\mathbf{n = 2 8} \\
\text { Median } \\
\text { (range) }\end{array}$ & $\begin{array}{c}\text { Vaccine-only } \\
\mathbf{n = 4 3} \\
\text { Median } \\
\text { (range) }\end{array}$ & $\begin{array}{c}\text { P value } \\
\text { (Mann-Whitney } \\
\text { test) }\end{array}$ \\
\hline Age in years & $18(3-44)$ & $25(1-52)$ & 0.20 \\
DDTT days & $10(2-142)$ & $14(1-147)$ & 0.42 \\
BT units & $2(0-18)$ & $3(0-40)$ & 0.87 \\
S. Bilirubin mg/dl & $0.8(0.6-5.8)$ & $0.8(0.5-4.6)$ & 1.00 \\
AST U/dl & $27(12-451)$ & $29(10-127)$ & 0.96 \\
ALT U/dl & $31.5(10-169)$ & $36(11-295)$ & 0.87 \\
ALP U/dl & $243(129-552)$ & $232(96-1270)$ & 0.71 \\
S. Protein g/dl & $6.35(4-7.6)$ & $6.8(4-9.5)$ & $0.02^{*}$ \\
S. Albumin g/dl & $3.55(2.1-4.6)$ & $3.9(2.3-4.8)$ & $0.02^{*}$ \\
S. Globulin g/dl & $2.75(1.9-4.3)$ & $2.9(1.7-5.1)$ & $0.21^{*}$ \\
Sex M/F & $22(44.9) /$ & $27(55.10) /$ & $0.12^{\#}$ \\
& $6(39.44)$ & $16(72.73)$ & \\
\hline ALL/AML & $20(52.63) /$ & $18(47.37) /$ & $0.01^{\#}$ \\
& $8(24.24)$ & $25(75.76)$ & \\
Age $\leq 18$ yrs/ & $20(71.42) /$ & $11(25.58) /$ & $0.0002^{\#}$ \\
$>$ 18 yrs & $8(28.58)$ & $32(74.42)$ & \\
\hline
\end{tabular}

HBIG: Hepatitis B immunoglobin; DDTT: Duration of diagnosis to received treatment; BT: Blood transfusion; AST: Aspartate aminotransferase; ALT: Alanine aminotransferase; ALP: Alkaline phosphatase

*done by two sample $t$ test; ${ }^{\#}$ done by Fisher's exact test

patients was 33 (46.48\%). Nine patients (12.67\%) died due to their disease and chemotherapy complications before the $2^{\text {nd }}$ dose of vaccine; thus, 62 patients received a $2^{\text {nd }}$ vaccine dose. Three patients died before receiving their $3^{\text {rd }}$ dose of vaccine; thus, 59 patients received a $3^{\text {rd }}$ vaccine dose. One patient died before receiving their $4^{\text {th }}$ dose of vaccine; thus, 58 patients received a $4^{\text {th }}$ vaccine dose.

In the vaccine-only group, $2.56 \%, 8.33 \%, 14.28 \%$ and $34.29 \%$ patients developed anti- HBs titer $\geq 10$ IU/L after the $1^{\text {st }}, 2^{\text {nd }}, 3^{\text {rd }}$ and $4^{\text {th }}$ doses of vaccine, respectively. In the HBIG-vaccine group, 91.30\%, $91.30 \%, 69.56 \%$ and $73.91 \%$ patients developed antiHBs titer $\geq 10 \mathrm{IU} / \mathrm{L}$ after the $1^{\text {st }}, 2^{\text {nd }}, 3^{\text {rd }}$ and $4^{\text {th }}$ doses of vaccine, respectively, and $8.69 \%, 8.69 \%, 30.43 \%$ and $26.09 \%$ patients had anti-HBs titer $<10 \mathrm{IU} / \mathrm{L}$ after the $1^{\text {st }}, 2^{\text {nd }}, 3^{\text {rd }}$ and $4^{\text {th }}$ doses of vaccine, respectively. Significantly statistical differences (Table 2) in anti-HBs titer ( $\geq 10 \mathrm{U} / \mathrm{L})$ were seen between the two vaccine groups after the $1^{\text {st }}, 2^{\text {nd }}$, $3^{\text {rd }}$ and $4^{\text {th }}$ doses of vaccine. Those who received HBIG maintained their anti-HBs titer $\geq 10 \mathrm{IU} / \mathrm{L}$ even one month after the $4^{\text {th }}$ dose of vaccine. In the vac- 
Table 2. Anti-HBs titer according to vaccine group at the different time points

$\begin{array}{lcc}\text { Parameters } \quad<10 \mathrm{IU} / \mathrm{L}, \quad \geq 10 \mathrm{IU} / \mathrm{L} & \begin{array}{c}\text { P value } \\ \text { (Fisher's } \\ \text { exact test) }\end{array}\end{array}$

\begin{tabular}{lccc}
\hline $\begin{array}{l}\text { One month after } 1^{\text {st }} \text { dose } \\
\text { HBIG-Vaccine }\end{array}$ & $2(8.69)$ & $21(91.30)$ & \\
$\mathrm{n}=23$, no (\%) & & 0.0001 \\
Vaccine-only & $38(97.43)$ & $1(2.56)$ & \\
$\mathrm{n}=39$, no (\%) & & &
\end{tabular}

One month after $2^{\text {nd }}$ dose

$\begin{array}{lccc}\text { HBIG-Vaccine } & 2(8.69) & 21(91.30) & \\ \text { n=23, no (\%) } & & & 0.0001 \\ \text { Vaccine-only } & 33(91.66) & 3(8.33) & \\ \text { n=36, no (\%) } & & & \\ \text { One month after } 3^{\text {rd }} \text { dose } & & & \\ \text { HBIG-Vaccine } & 7(30.43) & 16(69.56) & \\ \text { n=23, no (\%) } & & & \\ \text { Vaccine-only } & 30(85.71) & 5(14.28) & \\ \text { n=35, no (\%) } & & & \\ \text { One month after } 4^{\text {th }} \text { dose } & & & \\ \text { HBIG-Vaccine } & 6(26.09) & 17(73.91) & \\ \text { n=23, no (\%) } & & & \\ \text { Vaccine-only } & 23(65.71) & 12(34.29) & \\ \text { n=35, no (\%) } & & & \end{array}$

HBIG: Hepatitis B immunoglobin

cine-only group, after the 4th dose, anti-HBs titer $\geq 10$ IU/L was achieved in $34.29 \%$ of patients, which was a very small proportion compared to the HBIG group. In both groups, a subgroup analysis was done between the ALL vs AML groups and pediatric vs adult groups. No significant differences were found between the ALL vs AML groups or between the pediatric vs adult groups.

In the pediatric age group, $72.72 \%, 58.33 \%$, $47.61 \%$ and $41.37 \%$ patients developed anti-HBs titer $\geq 10 \mathrm{IU} / \mathrm{L}$ after the $1^{\text {st }}, 2^{\text {nd }}, 3^{\text {rd }}$ and $4^{\text {th }}$ doses of vaccine, respectively, whereas in the adult age group, $27.28 \%, 41.67 \%, 52.38 \%$ and $58.63 \%$ patients developed anti-HBs titer $\geq 10 \mathrm{IU} / \mathrm{L}$ after the $1^{\text {st }}, 2^{\text {nd }}, 3^{\text {rd }}$ and $4^{\text {th }}$ doses of vaccine, respectively. This showed that pediatric patients lost their anti-HBs titer gradually from the 1 st to the $4^{\text {th }}$ dose of vaccine. On the other hand, an increasing number of adult patients gained anti-HBs titer $\geq 10 \mathrm{IU} / \mathrm{L}$ gradually from the $1^{\text {st }}$ to the $4^{\text {th }}$ dose of vaccine. Statistical differences in antiHBs titer $\geq 10$ IU/L were seen between the two age groups after the $1^{\text {st }}(\mathrm{p}=0.002)$ and $2^{\text {nd }}(\mathrm{p}=0.01)$ dose of vaccine, but not after the $3^{\text {rd }}(p=0.40)$ and $4^{\text {th }}(p=1.00)$ dose of vaccine. Thus, more pediatric patients developed anti-HBs titer $\geq 10 \mathrm{IU} / \mathrm{L}$ after the $1^{\text {st }}$ and $2^{\text {nd }}$ doses of vaccine compared to adult patients. Though more adult patients gained protective anti-HBs titer gradually from the $3^{\text {rd }}$ to $4^{\text {th }}$ doses of vaccine, when compared to the pediatric age group, the difference was statistically insignificant.

In the ALL group, $81.81 \%, 70.84 \%, 47.62 \%$ and $55.17 \%$ patients developed anti-HBs titer $\geq 10 \mathrm{IU} / \mathrm{L}$ after the $1^{\text {st }}, 2^{\text {nd }}, 3^{\text {rd }}$ and $4^{\text {th }}$ doses of vaccine, respectively, whereas in the AML group, 18.19\%, $29.16 \%, 52.38 \%$ and $44.83 \%$ patients developed antiHBs titer $\geq 10 \mathrm{IU} / \mathrm{L}$ after the $1^{\text {st }}$ dose, $2^{\text {nd }}, 3^{\text {rd }}$ and $4^{\text {th }}$ doses of vaccine, respectively. After the $1^{\text {st }}$ dose of vaccine, a statistical difference in anti-HBs titer $\geq 10$ IU/L was seen between the ALL and AML groups. No statistically significant differences were found after administration of the other doses ( $p$ values: 0.06 after $2^{\text {nd }}$ dose, 0.28 after $3^{\text {rd }}$ dose and 1.00 after $4^{\text {th }}$ dose). A significant number of ALL patients developed protective antibody titer after the 1st vaccine dose compared to AML patients; thereafter, both groups behaved similarly.

One month after the $4^{\text {th }}$ dose of vaccine, out of 58 patients, 5 patients (8.6\%) were found HBsAgpositive. Among the HBsAg-positive patients, 1 (4.34\%) was in the HBIG group and the remaining 4 $(11.42 \%)$ were in the vaccine-only group. Of the HBsAg-positive patients, 3 had ALL and 2 had AML. No significant difference $(\mathrm{p}=0.63)$ in HBsAg positivity was found between the vaccine groups. After 210 days of follow up, none of the patients was found to be positive for anti-HCV or HIV antibody.

\section{Discussion}

A study from India showed that $47.8 \%$ of ALL patients were positive for HBsAg after therapy. In order to reduce the impact of HBV infection, schedules for active immunization, double doses of active immunization and both active and passive immunization against this infection have been investigated.

The HBsAg positivity rate (3\%) in our study is quite similar to that of other studies performed in the general population in India. But the anti-HBs positivity rate in our study is quite high (40\%) compared to other studies (18-20\%) performed from India. This is probably due to the increased awareness of hepatitis B vaccination in the general popu- 
lation. The HBsAg positivity rate of acute leukemia in this study was slightly high (3\%) compared to that of an older study (1.85\%) in ALL done by Marwaha et al. [2] from Chandigarh, India. It is probably due to the less sensitive method used for detection of HBsAg in 2001. Anti-HBs titer $\geq 10 \mathrm{IU} / \mathrm{L}$ was seen in more pediatric patients compared to adults, due to the increased awareness of hepatitis $B$ vaccination in the pediatric population.

Goyal et al. [3] showed that after administration of double-dose vaccine during induction, consolidation and maintenance (0-1-2-12 months) chemotherapy, $19.7 \%$ patients developed anti-HBs titers and anti-HBs titer $\geq 10 \mathrm{IU} / \mathrm{L}$ was achieved in only $10.5 \%$ of patients. They detected HBsAg in $48.79 \%$ of their patients during the course of treatment. Another study from India by Somjee et al. [7] showed that at the end of six doses of vaccine (0-1-2-3-4-12), 29.75\% of patients developed anti-HBs titers, and of them, only $18.9 \%$ had anti-HBs titer $\geq 10 \mathrm{IU} / \mathrm{L}$. In the course of treatment, $43 \%$ of patients developed HBsAg positivity. A similar dose schedule as in our study (0-1-2-6) was tried in adult patients with acute leukemia (ALL $\&$ AML) by Gurina et al. [8]. In 30 patients, the rate of antibody positivity was $50 \%$ after the 4 th dose of vaccine and $6.7 \%$ became infected with HBV over the three-year follow-up. A more intensive vaccination schedule (0-1-2-6-12) was used by Yetgin et al. [9] in 82 patients with childhood ALL. They found that the rate of antibody positivity was $35.4 \%$ after the $5^{\text {th }}$ dose of vaccine, and $4.8 \%$ became infected with HBV after the end of vaccination. Our results are quite similar with the Yetgin et al. trial. An exact comparison with other studies is not possible because different vaccination schedules were used. In our study, more patients (34.29\%) developed protective antibody titer after receiving their $4^{\text {th }}$ dose of vaccine compared with other trials done by Goyal et al. [3] and Somjee et al. [7]. This is possibly due to the more severe immunosuppressive chemotherapy schedule used in their study. In our study, after a seven-month follow-up period, a small number (11.42\%) of patients developed HBsAg positivity compared with other trials done by Goyal et al. and Somjee et al. This is due to improved infection control measures, safer blood supply in our hospital and the short duration of follow-up in our study. In spite of active immunization with recombinant DNA vaccine, some patients became infected with $\mathrm{HBV}$ infection. Thus, active immunization with recombinant DNA vaccine has a minimal role in these immunosuppressed patients while they are on aggressive therapy.

A total of 28 patients received both vaccine and HBIG. Passively transferred immunity generated high titers of antibodies in these patients in the first 3 months. However, once these were eliminated over a period of another 3 months, active immunization was unable to confer sustained protection at 7 months. Therefore, it should be stressed that passive prophylaxis alone needs to be administered during the entire course of aggressive chemotherapy. Kavakli et al. [4] studied 22 patients with leukemia who received HBIG (800 IU once per month for 3 doses), together with vaccine at a different intramuscular site. HBV infection was not observed in any of the patients at the $4^{\text {th }}$ and $12^{\text {th }}$ months of serological follow-up. At the end of the first year, the antibody response reached $85 \%$. In another study by Meral et al. [6], passive immunization with immunoglobulin (monthly for four doses) was given at the time of aggressive chemotherapy, and subsequently these patients were actively immunized with vaccine (40 mcg, 1-2-12 months) from the third month of maintenance therapy. Their rate of antiHBs positivity was $90.3 \%$ at the end of the four doses, and at the end of the three-year follow-up, only 5 patients $(16 \%)$ lost the protective antibody titers. In another Indian study by Somjee et al. [5], five doses of hepatitis B vaccine (ENGERIXSmithKline Beecham) along with HBIG (HEPABIGVHB Pharmaceuticals) were given in 31 ALL patients. Their rates of anti-HBs positivity were $89.6 \%$ at the end of 6 months, and at the end of 9 months, only 8 (42\%) patients had lost the protective antibody titer. The rate of HBV infection was $27 \%$ at the end of 9 months. In our study, $73.91 \%$ of patients had developed anti-HBs titer $\geq 10 \mathrm{IU} / \mathrm{L} 1$ month after the 4th dose of vaccine. This is a slightly inferior response compared to results of the Kavakli et al. [4], Meral et al. [6] and Somjee et al. [7] trials. The inferior response is possibly due to lesser doses of HBIG used in our trial (i.e. 2 doses of HBIG in our trial, 3 doses in Kavakli et al. trial, 4 doses in Meral et al. trial and 5 doses in Somjee et al. trial). Thus, a comparison of our study and other studies clearly shows that more doses of HBIG are required to achieve the maximum protective anti-HBs titers. Apart from that, HBIG may protect patients during the intensive chemotherapy period, but there must be sufficient antibody level during the entire period to decrease the rate of $\mathrm{HBV}$ infection in these patients. HBIG 
could be given during aggressive treatment where maximum immunosuppression exists in addition to increased chances of exposure. This could be used in combination with more doses of active immunization, which may result in higher rates of antibody response.

In normal individuals, the rate of seroconversion following hepatitis B vaccine is almost $96 \%$, and protective antibody levels can be achieved in 93\% [3]. In the present study, despite the use of a double dose of vaccine and a more intensified vaccination program, seroconversion could be achieved in only $34.29 \%$ and $73.91 \%$ of the patients in the vaccineonly and vaccine-HBIG groups, respectively. This is because immunosuppression in leukemic patients resulting from the disease as well as the use of steroids lead to diminished response to initial or booster vaccination. Therefore, passive immunization with hyperimmunoglobulin followed by active immunization starting during maintenance therapy or after cessation of intensive chemotherapy may be a better alternative to achieve permanent protective antibody titers.

In the HBIG group, subgroup analysis was done between the ALL vs AML and pediatric vs adult groups. No statistically significant differences were found between the ALL vs AML groups or between the pediatric vs adult groups. Thus, differences in age and disease were not responsible for development of protective antibody titer. HBsAg positivity rate was similar between the two vaccine groups in the short follow-up period (7 months). The outcome of long-term follow-up might be different in terms of HBsAg positivity. Thus, long- term followup will be required to determine the efficacy of vaccination and the HBsAg positivity rate.

In conclusion, HBIG may protect patients during the intensive chemotherapy period, but there must be sufficient antibody level during the entire period to decrease the rate of $\mathrm{HBV}$ infection in these patients. To increase the level of protective antibody titers ( $\geq 10 \mathrm{IU} / \mathrm{L}$ ), both active and passive immunization are required. A large prospective multicenter randomized controlled trial is needed to address this issue.

\section{Conflict of interest}

No author of this paper has a conflict of interest, including specific financial interests, relationships, and/or affiliations relevant to the subject matter or materials included in this manuscript.

\section{References}

1. Acharya SK, Panda SK. Hepatitis E virus: epidemiology, diagnosis, pathology and prevention. Trop Gastroenterol 2006;27:63-8.

2. Marwaha R, Rawat D, Chawla Y. Seroprevalence of hepatitis $\mathrm{B}$ and $\mathrm{C}$ viral infections at diagnosis and during the course of treatment in childhood malignancies. Med Pediatr Oncol 2001;37:166.

3. Goyal S, Pai SK, Kelkar R, Advani SH. Hepatitis B vaccination in acute lymphoblastic leukemia. Leuk Res 1998;22:193-5.

4. Kavakli K, Cetingul N, OztopS. Combined administration of hepatitis B vaccine and hepatitis B immunoglobin in children with cancer. Pediatr Hematol Oncol 1996;13:295-8.

5. Somjee S, Pai S, Parikh P, Banavali S, Kelkar R, Advani $\mathrm{S}$. Passive active prophylaxis against hepatitis $\mathrm{B}$ in children with acute lymphoblastic leukemia. Leuk Res 2002;26:989-92.

6. Meral A, Sevinir B, Gunay U. Efficacy of immunization against hepatitis B virus infection in children with cancer. Med Pediatr Oncol 2000;35:47-51.

7. Somjee S, Pai S, Kelkar R, Advani S. Hepatitis B vaccination in children with acute lymphoblastic leukemia: results of an intensified immunization schedule. Leuk Res 1999;23:365-7.

8. Gurina NM, Svedentsov EP, Shardakov VI, Cherepanova VV. Vaccine prophylaxis of viral hepatitis B in patients with acute leukemia. Ter Arkh 2008;80:27-9.

9. Yetgin S, Tavil B, Aytac S, Kuskonmaz B, Kanra G. Unexpected protection from infection by two booster hepatitis $B$ virus vaccination in children with acute lymphoblastic leukemia. Leuk Res 2007;31:493-6. 